Marcin Krawczuk

\title{
Wkład etiopistyki do badań nad piśmiennictwem wczesnochrześcijańskim Aethiopia Christiana i jej piśmiennictwo
}

W artykule postaram się opisać wkład etiopistyki do badań nad literaturą wczesnochrześcijańską. Skupię się w szczególności na zachowanych w tradycji etiopskiej tekstach wczesnochrześcijańskich, które zaginęły w innych rejonach świata chrześcijańskiego.

Przez etiopistykę rozumie się interdyscyplinarną naukę badającą historię, kulturę i języki Etiopii. W obrębie etiopistyki szczególne miejsce zajmuje filologia zajmująca się tekstami w języku gə’əz' ${ }^{1}$, której początki sięgają XVII wieku. Mianem literatury wczesnochrześcijańskiej określa się piśmiennictwo powstałe w kręgach chrześcijańskich od czasów apostolskich do II Soboru Nicejskiego (787 rok $)^{2}$. W artykule zwrócę także uwagę na rolę etiopistyki w poznawaniu tekstów żydowskich okresu międzytestamentalnego, które rzucają światło na moment formowania się wiary chrześcijańskiej.

Nie tylko teksty etiopskie mogą wnieść wiele do badań nad wczesnym Kościołem. W literaturze przedmiotu wielokrotnie pojawia się wątek Etiopii jako „żywego muzeum wczesnego chrześcijaństwa". Szereg archaizmów istniejących w liturgii i codziennej pobożności Etiopskiego Kościoła Ortodoksyjnego, przetrwanie w sztuce etiopskiej wczesnej chrześcijańskiej ikonografii, która nie była kontynuowana w innych kościołach, to, między innymi, zagadnienia ze wszech miar godne podję$\mathrm{cia}^{3}$. W niniejszym artykule ograniczę się jednak wyłącznie do kwestii filologicznych.

${ }^{1}$ Język ten, zaliczany do południowej grupy języków semickich, był do XIX wieku jedynym językiem piśmiennictwa etiopskiego, z wyjątkiem arabskiego używanego przez etiopskich muzułmanów. W XIX wieku funkcję tę przejął język amharski, ale gə‘əz pozostaje do dzisiaj językiem liturgicznym Etiopskiego Kościoła Ortodoksyjnego.

${ }^{2}$ Takie ramy czasowe przyjmuje na przykład J.M. Szymusiak, M. Starowieyski, Stownik wczesnochrześcijańskiego piśmiennictwa, Poznań 1971.

${ }^{3}$ Warto może wspomnieć w tym miejscu, iż obecność tych archaizmów wiązana jest często z szeroko dyskutowanym zagadnieniem „wpływu” bądź „substratu” żydowskiego w kulturze Etiopii. Chodzi tu o te zwyczaje czy fakty historyczne (jak na przykład powszechność obrzezania, przepisy alimentacyjne, wywodzenie dynastii panującej od króla Salomona), które są tłumaczo- 
Już u zarania badań naukowych w zakresie etiopistyki, po pewnym rozczarowaniu brakiem znaczenia etiopskiej wersji Biblii dla biblistyki w ogóle, zdano sobie sprawę z ogromnego znaczenia tekstów przetłumaczonych $\mathrm{w}$ starożytności na język gə‘วz. Początkowo głównym obiektem badań były teksty literatury międzytestamentalnej ${ }^{4}$, nieco później zidentyfikowano teksty hagiograficzne, historiograficzne i apologetyczne zachowane tylko w Etiopii, kwestią ostatnich lat są badania tekstów kanonicznych.

Wyjąwszy kilka osobliwych przykładów, teksty etiopskie istotne z punktu widzenia badań nad wczesnochrześcijańskim piśmiennictwem zostały przetłumaczone na język gə‘ $ə z \mathrm{w}$ Aksum (I-VII w.), państwie położonym na terenie dzisiejszej północnej Etiopii i Erytrei. Około roku 330 jego władca Ezana przyjął chrzest, tym samym włączając je do śródziemnomorskiej chrześcijańskiej oikumene ${ }^{5}$. Mimo że Aksum jest jednym z najstarszych chrześcijańskich państw na świecie, zadziwiająco mało wiemy o tym, jak przejawiało się przyjęcie nowej religii. Nie wiadomo w zasadzie nic o klerze czy biskupach. Dane archeologiczne wskazują, że kościoły zakładano na miejscach kultu przedchrześcijańskich bóstw ${ }^{6}$. Fakt, iż przetłumaczono $\mathrm{w}$ tym okresie pisma o charakterze monastycznym, czyni bardzo prawdopodobnym istnienie życia zakonnego, za sprawą którego chrześcijaństwo mogło docierać do szerokich warstw ludności.

Przyjęcie chrześcijaństwa przez władców Aksum stworzyło konieczność przetłumaczenia na język lokalny tekstów niezbędnych do krzewienia nowej religii i sprawowania jej liturgii. Teksty te $z$ bardzo nielicznymi wyjątkami przybywały do Etiopii z egipskich greckojęzycznych kręgów kościelnych ${ }^{7}$. Taki stan rzeczy trwał do upadku kultury aksumskiej, datowanego obecnie na połowę VII wie$\mathrm{ku}^{8}$. Po trwającym siedem wieków okresie, z którego nie są znane niemal żadne teksty, literatura gə‘ $ə z$ odżywa po roku 1270, ale świat dookoła Etiopii zmienia się. Egipt, z którego napływały do Etiopii teksty, został podbity przez Arabów, w Kościele koptyjskim greka wyszła całkowicie z użycia, język koptyjski coraz bardziej ogranicza się tylko do języka liturgii, podstawowym językiem piśmiennictwa

ne bądź to przez chęć naśladowania przez Etiopczyków starotestamentowych Izraelitów, bądź to przez starożytne kontakty Etiopii z jakąś formą judaizmu. Streszczenie głównych wątków i bibliografię przedmiotu znajdzie czytelnik m.in. W: W. Witakowski, Judiska inslag $i$ det kristna Etiopien, „Nordisk Judaistik” 1996, 17, 1-2 i U. Schattner-Rieser, Empreintes bibliques et emprunts juifs dans la culture éthiopienne, „Journal of Eastern Christian Studies” 2012, 64, 1-2.

${ }^{4}$ Pod tym terminem rozumie się „pisma pochodzenia żydowskiego $\mathrm{z}$ ostatnich wieków przed Chrystusem oraz z początków chrześcijaństwa, które nie weszły do kanonu Pisma Świętego". Por. S. Mędala, Wprowadzenie do literatury międzytestamentalnej, Kraków 1994, s. 5.

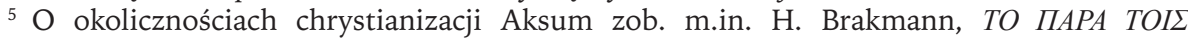

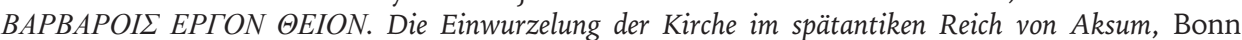
1994; Ch. Haas, Mountain Constantines. The christianization of Aksum and Iberia, „Journal of Late Antiquity" 2008, t. I, nr 1 ().

${ }^{6}$ M. Wendowski, H. Ziegert, Aksum at the transition to Christianity, „Annales d'Éthiopie” 2003, t. XIX, s. 224.

${ }^{7}$ L .Ricci, Letteratura in lingua ghe'éź, [w:] Storia delle letterature d'Oriente, red. O. Botto, Milano 1969, s. 813.

${ }^{8}$ D. W. Phillipson, Foundations of an African civilization. Aksum and the Northern Horn, 1000 B.C.-A.D. 1300, Woodbridge 2012, s. 223. 
chrześcijańskiego staje się arabski. To z niego Etiopczycy będą odtąd dokonywać przekładów.

\section{Czego szuka patrolog w literaturze etiopskiej?}

Na literaturę etiopską prócz przekładów z greki i arabskiego składają się liczne oryginalne teksty, jednak z punktu widzenia badaczy piśmiennictwa wczesnochrześcijańskiego te pierwsze mają o wiele większe znaczenie ${ }^{9}$. Patrolodzy szukają w literaturze etiopskiej wersji tekstów starożytnych z nadzieją, że uda się odkryć teksty niezachowane w innych językach lub pełniejsze wersje tekstów, które inne literatury przechowały we fragmentach. Najcenniejsze z takiego punktu widzenia są oczywiście teksty przetłumaczone w Aksum jako przełożone bezpośrednio z greckiego oryginału, od którego dzieli je na dodatek stosunkowo niewielki odstęp czasowy.

Teksty w języku gə‘əz były spisywane na pergaminowych rękopisach. Najstarsze zachowane rękopisy etiopskie (są to bez wyjątku kodeksy zawierające wybrane księgi Biblii) pochodzą z XI wieku ${ }^{10}$. Dopiero od XIV wieku liczba rękopisów wyraźnie wzrasta. Oznacza to, iż badacze muszą w olbrzymiej objętościowo literaturze gə’əz odnaleźć teksty przełożone z greki w starożytności.

Identyfikacja w korpusie etiopskiej literatury tekstów przetłumaczonych z greki nie jest jednak zadaniem łatwym. Jak wspomniałem, nie dotrwały do naszych czasów żadne rękopisy z okresu świetności państwa Aksum, podstawy tłumaczenia trzeba zatem dociekać, opierając się na danych wewnątrztekstowych, jako że kolofony rękopisów niemal nigdy nie podają języka oryginału ${ }^{11}$. Na grecki język oryginału mogą wskazywać takie cechy językowe jak specyficzne kalki składniowe czy zapis imion własnych ${ }^{12}$.

Identyfikację tekstów aksumskich utrudnia również fakt, że w późniejszym czasie były one włączane do obszernych kompilacji razem z tekstami tłumaczonymi z arabskiego. Jako przykład takiej kompilacji można podać zbiór opowieści o męczennikach Gadla sama'ətāt. Ponadto po restytucji dynastii salomońskiej ${ }^{13}$ i za-

${ }^{9}$ Skądinąd w oryginalnych dziełach etiopskich pochodzących z okresu po 1270 roku mogą znajdować się obszerne cytaty $\mathrm{z}$ dzieł przetłumaczonych $\mathrm{z}$ greki $\mathrm{w}$ okresie aksumskim. $\mathrm{Z}$ taką sytuacją mamy do czynienia na przykład w pochodzącym z XV wieku traktacie antyheretyckim Mașhafa məśtị („Księga tajemnic”) autorstwa Giyorgisa z Sägla.

${ }^{10} \mathrm{O}$ rękopisach etiopskich zob. m.in.: E. Balicka-Witakowska, Z dziejów książki etiopskiej, „Studia o Książce” 1975, t. V, s. 65-91.

${ }^{11}$ S. Uhlig, Kolophone und zeitgenössische Vermerke in äthiopischen Handschriften, „Internationale Kirchliche Zeitschrift" 1986, t. XCIV, s. 311.

${ }^{12}$ Nie powstał dotychczas systematyczny i podparty wszechstronnymi badaniami filologicznymi wykaz cech wskazujący jednoznacznie na greckie Vorlage tekstu etiopskiego, natomiast zestawienie cech wskazujących jednoznacznie na arabską podstawę tłumaczenia znaleźć można w: M. Kropp, Arabisch-äthiopische Übersetzungstechnik am Beispiel der „Zena Ayhud (Yosippon)” und des „Tarikä Wäldä- 'Amid”, „Zeitschrift der Deutschen Morgenländischen Gesellschaft” 1986, t. CXXXVI, s. 320-334.

${ }^{13} \mathrm{~W}$ historiografii etiopskiej pod tym pojęciem rozumie się przejęcie władzy cesarskiej 
cieśnieniu więzów z Kościołem koptyjskim doszło w Etiopii (zapewne z inicjatywy przysyłanego z Aleksandrii kleru) do szeroko zakrojonej rewizji tekstów przejętych $z$ epoki aksumskiej. Celem tej rewizji było nie tylko filologiczne „poprawienie” ich względem tekstów koptyjskich $\mathrm{w}$ języku arabskim ${ }^{14}$, ale przede wszystkim analiza aksumskiej spuścizny literackiej pod kątem jej zgodności z teologią Kościoła koptyjskiego. Gdy jakiś tekst został uznany za niedostatecznie prawomyślny, zaprzestawano jego kopiowania ${ }^{15}$. W innych wypadkach dzieło tłumaczone $z$ greki przestawało być kopiowane, a zamiast niego stosowano jego przekład dokonany z tekstu arabskiego. Ta „kopto-arabizacja” literatury etiopskiej sprawiła, że dla szeregu tekstów mamy podwójne recenzje: jedną grecką, drugą arabską ${ }^{16}$. Tak jak w całym świecie chrześcijańskim powszechne są również fałszywe atrybucje, tym liczniejsze, im bardziej czczona jest dana postać ${ }^{17}$.

Zostają też problemy czysto praktyczne. Rękopisy ginęły w niespokojnych czasach, niszczały i były wyrzucane jako nieprzydatne. Te, które przetrwały, są rozrzucone po olbrzymim obszarze Etiopii i Erytrei ${ }^{18}$, trudno dostępne i niejednokrotnie zazdrośnie strzeżone w klasztorach przed wzrokiem zagranicznych badaczy.

\section{Etiopskie wersje dzieł znanych z innych języków}

W Aksum przetłumaczono $z$ greki szereg tekstów dobrze znanych $z$ innych obszarów starożytnego chrześcijaństwa. Obok tekstu fundamentalnego, czyli Starego i Nowego Testamentu, do tej grupy tekstów można zaliczyć dzieła teologiczne: Pasterza Hermasa ${ }^{19}$, Fizjologos, O Antychryście Hipolita Rzymskiego ${ }^{20}$ homilie

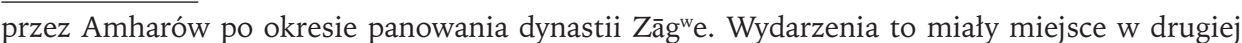
połowie XIII wieku. W świetle ideologii władców tej dynastii są oni następcami królów Aksum (stąd restytucja) i jednocześnie potomkami Menelika, syna biblijnego króla Salomona, który sprowadził do Etiopii Arkę Przymierza. Por. A. Bartnicki, J. Mantel-Niećko, Historia Etiopii, Wrocław-Warszawa-Kraków 1972, s. 36-39.

${ }^{14}$ Gruntownej rewizji poddano między innymi tekst Biblii, którą przełożono w czasach aksumskich z greki, w XIV wieku dokonano zaś wielu zmian, biorąc za podstawę tekst arabski. Por. M. Knibb, Translating the Bible. The Ethiopic version of the Old Testament, Oxford 1999, s. 33-34.

15 Taki los spotkał na przykład Pasterza Hermasa i Wniebowstapienie Izajasza. Por. G. Lusini, Naufragio e conservazione di testi cristiani antichi: il contributo della tradizione etiopica, „Annali - Università degli Studi di Napoli L'Orientale" 2009, t. LXIX, s. 74-76.

${ }^{16}$ Zjawisko to można dokładnie prześledzić na przykładzie apokryficznej biografii apostoła Marka, por. G. Lusini, Gli Atti apocifici di Marco, „Aethiopica” 2009, t. XII, s. 71.

${ }_{17} \mathrm{~W}$ literaturze przedmiotu znaleźć można w zasadzie tylko jedną próbę gruntownej analizy etiopskiej spuścizny jednego z Ojców Kościoła (chodzi o Jana Chryzostoma) pod kątem oddzielenia fałszywych atrybucji od autentycznych dzieł przetłumaczonych na język gə‘əz: G. Lusini, Appunti sulla patristica greca di tradizione etiopica, „Studi Classici e Orientali” 1988, t. XXXVIII, s. 469-493.

${ }_{18}$ Biblioteki klasztorne, w których znajduje się dużo tekstów o genezie aksumskiej, mieszczą się między innymi w klasztorach Gunda Gunde, Dabra Ḥayq 'Gsțifānos, Dāgā 'Asțifānos. Nie brak jednak przypadków znajdowania nadzwyczajnych tekstów w miejscach zupełnie niepozornych.

19 A. d'Abbadie (wyd. i tł.), Hermae Pastor, Lipsiae 1860.

20 A. Caquot, Une version ge'ez du traité d'Hippolyte de Rome sur l'Antichrist, „Annales d'Éthiopie” 1965, t. VI, nr 1, s. 165-214. 
Jana Chryzostoma o świętym Tomaszu ${ }^{21}$, List 70 Cypriana z Kartaginy ${ }^{22}$, Ancoratus Epifaniusza z Salaminy, dzieła monastyczne, jak reguła zakonna Pachomiusza ${ }^{23}$, żywoty Pawła Pustelnika i Antoniego, być może także liturgiczne.

Istnienie wersji etiopskich powyższych tekstów jest istotne i prowokuje postawienie wielu ważkich pytań badawczych. Niekiedy, jak w przypadku traktatu O Antychryście, można dzięki tym wersjom zrekonstruować zaginione $\mathrm{w}$ innych wersjach fragmenty dzieła. Nie są to jednak zjawiska, które $z$ punktu widzenia patrologów zainteresowanych poszukiwaniem zaginionych tekstów starożytnych można by określić jako sensacyjne.

Wzmożony napływ tekstów patrystycznych następuje dopiero w drugim, arabskim okresie literatury etiopskiej. Większość dzieł klasycznych tekstów Ojców takich jak Jan Chryzostom, Efrem Syryjski czy Bazyl z Cezarei pochodzi z tego właśnie okresu i jest przełożona $\mathrm{z}$ arabskiego ${ }^{24}$.

\section{Etiopia arką dla tekstów wczesnochrześcijańskich}

Sensacji jednak w Etiopii nie brakuje. Za takowe można bez wahania uznać przetrwanie $\mathrm{w}$ Etiopii dzieł, które zaginęły w reszcie świata chrześcijańskiego bądź zachowały się tylko szczątkowo. Jakakolwiek dyskusja o tych tekstach jest możliwa tylko w oparciu o materiał etiopski. Postaram się wymienić takie właśnie teksty, zwracając przy tym uwagę na ich różnorodność i zróżnicowaną historię transmisji.

Zacząć wypada od tekstów, które nie są co prawda chrześcijańskie, ale zważywszy na datę powstania ich oryginałów, rzucają światło na epokę, w której zaczęła kształtować się religia chrześcijańska. Księga Henocha ${ }^{25}$ i Księga Jubileuszów ${ }^{26}$ zostały skompilowane $\mathrm{w}$ środowisku żydowskim $\mathrm{w}$ pierwszych wiekach przed Chrystusem i zawierają wiele materiału o charakterze apokaliptycznym i kalendarzowym. Innym ważnym apokryfem Starego Testamentu, jednak już o wyraźnie chrześcijańskim charakterze, jest pochodzące z II wieku n.e. Wniebowstąpienie Izajasza ${ }^{27}$.

${ }^{21}$ F. M. Esteves Pereira, Duas homílias sôbre S. Tomé atribuídas a S. João Crisóstomo, „Boletim da Segunda Classe" 1913/1914, t. VIII, s. 151-182.

${ }^{22}$ A. Bausi, L'Epistola 70 di Cipriano di Cartagine in versione etiopica, „Aethiopica” 1998, t. I, s. $101-130$.

${ }^{23}$ A. Dillmann, Chrestomatia Aethiopica, Lipsiae 1866, s. 57-69.

${ }^{24}$ Najważniejszym etiopskim florilegium patrystycznym jest Haymanota 'abaw (,Wiara ojców”). Inne ważne zbiory tekstów wczesnochrześcijańskich, które do Etiopii weszły poprzez język arabski, to m.in. Gabra hemamat („Dzieje męki”, wybór pism patrystycznych przeznaczonych do odczytywania w Wielkim Tygodniu) oraz Gadla hawaryat („Żywoty apostołów”, apokryficzne dzieje apostolskie).

25 The Ethiopic Book Henoch, wyd. M. Knibb, Oxford 1978. Starsze wydanie: Liber Henoch, wyd. A. Dillmann, Lipsiae 1851.

${ }^{26}$ The Book of Jubilees - a critical text, wyd. J. Vanderkam, Lovanii 1989. Istnieje również starsze wydanie, oparte na dużo mniejszej bazie rękopiśmiennej: The Ethiopic version of the Hebrew Book of Jubilees, wyd. R.H. Charles, Oxford 1895.

27 Ascensio Isaiae: Textus, wyd. L. Perlone, E. Norelli, Turnhout 1995. 
Apokryfem związanym z działalnością apostołów jest z kolei Epistula apostolorum $^{28}$. Apokryf ten został skompilowany około 170 roku n.e. i ma formę rozmowy apostołów z Chrystusem, głównie o kwestii zmartwychwstania.

Istotną grupą wśród tekstów przetłumaczonych na język etiopski w starożytności, i w nim tylko zachowanych, są teksty dokumentujące wczesne dzieje Kościoła w Egipcie ${ }^{29}$. Jak wiadomo, Etiopski Kościół Ortodoksyjny do 1959 roku był diecezją Kościoła koptyjskiego. Ta instytucjonalna podległość, będąca dla Etiopczyków nierzadko kłopotem ${ }^{30}$, sprawiła jednak, że w Etiopii zachowały się teksty o olbrzymim znaczeniu dla poznania literackiej produkcji Aleksandrii, jednego z czterech, obok Konstantynopola, Jerozolimy i Antiochii, patriarchatów starożytnego wschodniego chrześcijaństwa o genezie apostolskiej.

W okresie aksumskim przetłumaczono na gə‘əz obszerny wybór pism (głównie) egipskich Ojców Kościoła, w którym poczesne miejsce zajmują homilie Cyryla Aleksandryjskiego, od którego pochodzi nazwa całego zbioru, czyli Qerallos ${ }^{31}$. Spośród zebranych tam tekstów tylko po etiopsku zachowały się traktat Sewerusa z Synnady, Firmusa z Cezarei, homilie Cyryla Aleksandryjskiego o Melchizedeku. We wspomnianym korpusie biografii męczenników Gadla Sama'stāt zachowana jest biografia Fileasa ${ }^{32}$, żyjącego w IV wieku biskupa Tmui, którego fragmenty greckie znane są tylko z papirusów.

W 1999 roku został odkryty rękopis, który za jego wydawcą określa się mianem Aksumite Collection ${ }^{33}$. Jest to zbiór tekstów w większości z zakresu prawa kanonicznego i liturgicznego. Oryginał tego zbioru powstał pomiędzy rokiem 477 a 687 (sam rękopis pochodzi z XIV wieku). Kolekcja ta zawiera obszerne i cenne nowe materiały dotyczące historii patriarchatu Aleksandrii, znane dotychczas tylko $z$ nielicznych fragmentów łacińskich ${ }^{34}$, oraz list Tymoteusza II Ailurosa do Aleksandryjczyków.

Warto wspomnieć również o trzech przypadkach, gdy dzięki późnemu tłumaczeniu z języka arabskiego w Etiopii zachowało się zaginione gdzie indziej dzieło starożytne. Kronika Jana $\mathrm{z} \mathrm{Nikiu}^{35}$ została napisana po koptyjsku w połowie 1913.

${ }^{28}$ Le Testament en Galilée de Notre-Seigneur Jésus-Christ: texte éthiopien, wyd. L. Guerrier, Paris

${ }^{29} \mathrm{~W}$ ostatnich latach skądinąd akcentuje się znaczenie etiopistyki dla odtworzenia koptyjsko-arabskiej tradycji literackiej, która poważnie ucierpiała wskutek wielowiekowej dominacji arabskiej. Por. P. Marrassini, Literatura etiopska, [w:] P. Siniscalco i in., Starożytne kościoty wschodnie, Kraków 2013, s. 140.

${ }^{30}$ Przykładowo, tylko wyznaczony przez Aleksandrię metropolita mógł wyświęcać księży sprawujących posługę w kościołach całego kraju lub koronować nowego władcę.

${ }^{31}$ Q rellos 1. Der Prosphonetikos „Über den rechten Glauben” des Kyrillos von Alexandrien an Theodosios II, wyd. B.M. Weischer, Glückstadt 1973.

${ }^{32}$ La versione etiopica degli Acta Phileae nel Gadla samā'tät, wyd. A. Bausi, Napoli 2002. Idem, The Aksumite background of the Ethiopic „Corpus Canonum”, [w:] Proceedings of the Fifteenth International Conference of Ethiopian Studies, Hamburg 21-25 July 2003, red. S. Uhlig, Wiesbaden 2006, s. 532-541.

33 A. Bausi, La „Collezione aksumita” canonico-liturgica, „Adamantius” 2006, t. XII, s. 43-70.

${ }^{34}$ Jest to również unikat $z$ etiopskiej perspektywy - jeden $z$ kilku zaledwie tekstów historiograficznych literatury aksumskiej.

${ }^{35}$ Chronique de Jean, évêque de Nikiou, wyd. i tłum. H. Zotenberg, Paris 1883. 
VII wieku. Przez wiele lat poświęcano jej stosunkowo mało uwagi w porównaniu z innymi dziełami późnoantycznej historiografii. W ostatnich latach jednak akcentuje się jej znaczenie jako cennego źródła, zwłaszcza do poznania dziejów arabskiego podboju Egiptu ${ }^{36}$. W 1601 roku z jej wersji arabskiej dokonano tłumaczenia na gə‘əz. Zarówno wersja koptyjska, jak i arabska w całości zaginęły, wersja etiopska daje zatem jedyną możliwość zapoznania się z tym dziełem. $Z$ kolei tak zwana Ksiega Koguta ${ }^{37}$, apokryf pasyjny opisujący ostatnie trzy dni życia Chrystusa, reprezentowany jest przez rękopisy późniejsze niż XVI wiek, przekazujące jednak dużo lepszy tekst niż nieliczne zachowane fragmenty arabskie. Wnikliwa analiza treści dzieła sugeruje, iż mamy do czynienia z tekstem późnoantycznym z V lub VI wieku, zawierającym szereg interesujących archaizmów, jak na przykład motyw świętego Pawła jako łotra nakładającego Chrystusowi koronę cierniową. Kolejny cenny apokryf Nowego Testamentu zachowany tylko po etiopsku to Apokalipsa Piotra ${ }^{38}$. Tekst zaświadczony tylko przez dwa rękopisy jest jednym z pierwszych dzieł chrześcijańskich zawierających opisy pośmiertnego potępienia grzeszników. Powyższe przykłady pokazują, jak stosunkowo późne teksty mogą zawierać bardzo stare tradycje. Obrazują ponadto, że dzieła tłumaczone $\mathrm{z}$ arabskiego również mogą mieć duże znaczenie dla wczesnochrześcijańskiego piśmiennictwa.

Warto wspomnieć, że w przypadku sporej części omawianych powyżej dzieł poważne badania naukowe ( $\mathrm{w}$ tym ich fundamentalny element, czyli krytyczna edycja tekstów) miały miejsce w ciągu ostatnich dwudziestu-trzydziestu lat. Należy mieć nadzieję, iż ten pozytywny trend doprowadzi do przywrócenia etiopistyce należnego jej miejsca w badaniach nad piśmiennictwem wczesnochrześcijańskim.

\section{Bibliografia}

d'Abbadie A. (wyd. i tł.), Hermae Pastor, Brockhaus, Lipsiae 1860.

Balicka-Witakowska E., Z dziejów książki etiopskiej, „Studia o Książce” 1975, t. V.

Bartnicki A., J. Mantel-Niećko, Historia Etiopii, Zakład Narodowy im. Ossolińskich, Wrocław-Warszawa-Kraków 1972.

Bausi A., L'Epistola 70 di Cipriano di Cartagine in versione etiopica, „Aethiopica” 1998, t. I.

Bausi A. (wyd.), La versione etiopica degli Acta Phileae nel Gadla samā'tāt, Istituto Universitario Orientale, Napoli 2002.

Bausi A., La Collezione aksumita canonico-liturgica, „Adamantius” 2006, t. XII.

${ }^{36}$ Por. np. J.D. Howard-Johnston, Witnesses to a world crisis: historians and histories of the Middle East in the seventh century, Oxford-New York 2010, s. 181-189; P. Booth, Shades of Blues and Greens in the Chronicle of John of Nikiou, „Byzantinische Zeitschrift” 2011, t. CIV, s. 555-601.

${ }^{37}$ Tekst pozostaje niewydany. Szczegółowe jego omówienie zob. P. Piovanelli, Exploring the Ethiopic „Book of the Cock”, an apocryphal passion gospel from Late Antiquity, „Harvard Theological Review" 2003, t. XCVI, nr 4, s. 427-454.

38 P. Marrassini, L'Apocalisse di Pietro, w: P. Marrassini, Y. Beyene, R. Fattovich, A. Triulzi (red.), Etiopia e oltre. Studi in onore di Lanfranco Ricci, Napoli 1994, s. 171-232. 
Bausi A., The Aksumite background of the Ethiopic „Corpus Canonum”, [w:] Proceedings of the Fifteenth International Conference of Ethiopian Studies, Hamburg 21-25 July 2003, red. S. Uhlig, Harrassowitz Verlag, Wiesbaden 2006.

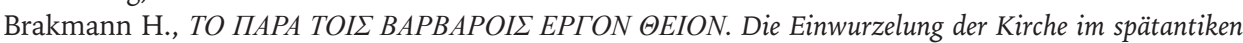
Reich von Aksum, Borengässer, Bonn 1994.

Booth P., Shades of Blues and Greens in the Chronicle of John of Nikiou, „Byzantinische Zeitschrift” 2011, t. CIV.

Caquot A., Une version ge'ez du traité d'Hippolyte de Rome sur l'Antichrist, „Annales d'Éthiopie” 1965, t. VI, nr 1 .

Charles R.H. (wyd.), The Ethiopic version of the Hebrew Book of Jubilees, Clarendon Press, Oxford 1895.

Dillmann A. (wyd.), Liber Henoch, C.G. Vogel, Lipsiae 1851.

Dillmann A., Chrestomatia Aethiopica, T.O. Weigel, Lipsiae 1866.

Guerrier L. (wyd.), Le Testament en Galilée de Notre-Seigneur Jésus-Christ: texte éthiopien, Firmin-Didot Paris 1913.

Haas Ch., Mountain Constantines. The christianization of Aksum and Iberia, „Journal of Late Antiquity” 2008 , t. I, nr 1.

Howard-Johnston J.D., Witnesses to a world crisis: historians and histories of the Middle East in the seventh century, Oxford University Press, Oxford-New York 2010.

Knibb M. (wyd.), The Ethiopic Book Henoch, Clarendon Press, Oxford 1978.

Knibb M., Translating the Bible. The Ethiopic version of the Old Testament, published for the British Academy by Oxford University Press, Oxford 1999.

Kropp M., Arabisch-äthiopische Übersetzungstechnik am Beispiel der Zena Ayhud (Yosippon) und des Tarikä Wäldä- 'Amid, „Zeitschrift der Deutschen Morgenländischen Gesellschaft” 1986, t. CXXXVI.

Lusini G., Appunti sulla patristica greca di tradizione etiopica, „Studi Classici e Orientali” 1988, t. XXXVIII.

Lusini G., Gli Atti apocifici di Marco, „Aethiopica” 2009, t. XII.

Lusini G., Naufragio e conservazione di testi cristiani antichi: il contributo della tradizione etiopica, „Annali - Università degli Studi di Napoli L'Orientale" 2009, t. LXIX.

Marrassini P., L'Apocalisse di Pietro, [w:], Etiopia e oltre. Studi in onore di Lanfranco Ricci, red. P. Marrassini, Y. Beyene, R. Fattovich, A. Triulzi, Istituto Universitario Orientale, Napoli 1994.

Marrassini P., Literatura etiopska, [w:] P. Siniscalco i in., Starożytne kościoty wschodnie, Wydawnictwo Petrus, Kraków 2013.

Mędala S., Wprowadzenie do literatury międzytestamentalnej, The Enigma Press, Kraków 1994.

Pereira F. M. Esteves, Duas homílias sôbre S. Tomé atribuídas a S. João Crisóstomo, „Boletim da Segunda Classe" 1913/1914, t. VIII.

Perlone L., Norelli E. (wyd.), Ascensio Isaiae: Textus, Brepols, Turnhout 1995.

Phillipson D.W., Foundations of an African civilization. Aksum and the Northern Horn, 1000 B.C.-A.D. 1300, James Currey, Woodbridge 2012.

Piovanelli P., Exploring the Ethiopic „Book of the Cock”, an apocryphal passion gospel from Late Antiquity, „Harvard Theological Review” 2003, t. XCVI, nr 4.

Ricci L., Letteratura in lingua ghe'éź, [w:] Storia delle letterature d'Oriente, red. O. Botto,F. Vallardi, Milano 1969.

Schattner-Rieser U., Empreintes bibliques et emprunts juifs dans la culture éthiopienne, „Journal of Eastern Christian Studies" 2012, t. LXIV, nr 1-2.

Szymusiak J.M., M. Starowieyski, Stownik wczesnochrześcijańskiego piśmiennictwa, Księgarnia św. Wojciecha, Poznań 1971.

Uhlig S., Kolophone und zeitgenössische Vermerke in äthiopischen Handschriften, „Internationale Kirchliche Zeitschrift" 1986, t. XCIV.

Wendowski M., Ziegert H., Aksum at the transition to Christianity, „Annales d'Éthiopie” 2003, t. XIX. Witakowski W., Judiska inslag i det kristna Etiopien, „Nordisk Judaistik” 1996, t. XVII, nr 1-2.

Vanderkam J. (wyd.), The Book of Jubilees - a critical text, E. Peeters, Lovanii 1989.

Weischer B. M. (wyd.), Qērellos 1. Der Prosphonetikos „Über den rechten Glauben” des Kyrillos von Alexandrien an Theodosios II, Augustin, Glückstadt 1973.

Zotenberg H. (wyd. i tłum.), Chronique de Jean, évêque de Nikiou, Imprimerie Nationale, Paris 1883. 